\title{
Creativity Development in Informatics Teaching Using the Project Focus
}

\author{
http://dx.doi.org/10.3991/ijep.v3i1.2342 \\ Walfredo González Hernández \\ Universidad de Matanzas, Matanzas, Cuba
}

\begin{abstract}
The development of creativity is necessary for all professionals and universities can not be exempted from it. According to studies (Acentura, 2007) is one of creativity does not develop skills in universities. This urgency becomes even more pressing when it comes to career information in the present conditions of production and consumption of information. This paper presents a practical implementation of the project approach in two countries to develop creativity in students of public universities.
\end{abstract}

Index Terms - Informatics Teach, Creativity

\section{INTRODUCTION}

The use of projects in teaching computer science is called by different authors (Exposito, 2005; Gonzalez, 2006; Estrada, 2005) as the project approach. This element considers the pursuit of future projects to be undertaken by students in practice. Projects are determined by the students in their interaction with practice according to needs and possibilities of computerization. The determination of future projects without even mastering the tools necessary fosters student intellectual audacity.

This reality becomes a source of man's creation and the students are educated in the search for new problems, as Lerner considerations (Martinez, 1988; Hernandez, 1999; Mitjáns, 1997) among other authors develop creativity . Integrating student - really - teaching, promotes the work of students acquire a social character both by the involvement of software developed for the business school or system and develop relationships with the rest of the group in the solution problems (Craft, 2008; Gonzalez, 2004; Gonzalez, 1997; Kampylis, P., E. Berki, Saariluoma P., 2009, Martinez, 1999). Previously raised involves the analysis of the situation and a reflective stance to criticism and questions

The transformation of reality by the student from the computerization process and selection of the necessary tools demonstrate the active nature of the regulatory function of his personality matters necessary in the development of creativity. This transformation process should occur on the mental playing an important role of the imagination, thus contributing to its development.

The projects are under consideration by the teacher who determines if they are in correspondence with the student and programming skills to receive. From the search begins life cycle of a software until concludes with the set-up and maintenance. The problems of individual project motivate students towards a solution and they are of course the knowledge that in turn generate problematic situations for other students which develops cognitive activity necessary for creativity. (Gonzalez, 1999; Zorana, 2009; Glazer,
2009; Gonzalez, 2006; Zorana, 2009; Kampylis "et al. \& rdquo, 2009)

In every encounter, from the previous interaction between student - teacher - group, defines the problematic situations for the remaining students. It is the teacher who decides the problem situation to occur earlier in the meeting based on group interaction and the development of student projects.

For the solution of the proposed programming is necessary for students to master the software engineering techniques that allow them to design the software to program it and then, in this process, the formation of an object-oriented design which allows a better model reality programming.

The project-based teaching is that teaching in which the basis is a project where the contents are expressed to teach students and the solution of each of the parts of this project is the new knowledge which they are appropriated. Has its roots in the problem based learning to which the author adds with minimum requirements as it must be in line with the objectives and the knowledge system of the year.

The project defines the task at hand throughout the course by the student that, if proposed by the author, comes from a company or a school. In this context the student is solving a real problem which has two functions, first is a student who is taking over the contents and on the other computer is as a process of computerization in a social context where takes most of the decisions. This dual role of student promotes the student to acquire professional skills in their training which is an element that contributes to the formation of professional interests in students. (Craft, 2008, de la Torre, 2002; Martinez, 1999; Shari, 2001).

Assuming the project approach implies for the student to have experiences in programming, direct the software construction process formulated to meet objectives, consider the solution of these objectives by regulating their actions consciously. This action of the practice promotes student place the student "... in the context of everyday social relations as being transformative and therefore critical, reflective, and proactive problematizador, can reshape and find new meaning in interactive situations their environment, professional and personal life activity "(D'Angelo, 2002) related to what he calls Personal Development (Professional) Creator (DPC)

Another approach in the teaching of computer science in Cuba recognized by several authors (Kudriatsev, TV, 1967, Expósito, 2010; González, 2004) is the teaching problem. Martinez (1995) suggests four basic types of problematic situations: 
- the mismatch between the skills and the demands of the task at hand.

- the contradiction between the theoretical and the practical possibility of its solution.

- the contradiction between knowledge and new operating conditions.

- the contradiction between the known and the unknown.

However, for the teaching of Computing the author acknowledges that there are several types of problematic situations given by the characteristics of this science as a realization of these general:

- No correspondence between the concept, model or procedure and the requirements of the task: This situation is in line with the first given by Marta Martínez (1995). The student does not know the concept and / or the procedure that allows to solve the task. To solve problems associated with the determination of a value and comparison with previous values is necessary to introduce the concept of settlement. The solution of the problem is given in the array concept as variable type and establishing operations in computing expression.

- Contradiction between the concept, model and / or the procedure and its expression in a computer system: The student knows various concepts or models but not how they are managed by a computer system or computer science. In this case can be find concepts like cycle, variable, column, row. The first concept is taught from the construction of the pseudo code is presented in contradiction coding algorithm obtained.

- No correlation between the expression of a concept computer in another system in the same family and the system used. This situation can be found in the students who have prepared in Pascal and go to another programming language like $\mathrm{C}++$ or Java. In this case students are mainly based on the analogy and the system helps to solve the problem. It becomes a problem for those students whose teacher development lets them know what is sought. The computing experience plays a key role.

- Contradiction between the potential of the system and the task at hand: teaching is typical of systems that are updated versions of others with whom already own or the student already knows. It is in the teaching of new language instructions for the task.

- Contradiction between the algorithm, the pseudo code and its implementation in a system: The contradiction lies in the possibility of algoritmizar the process, however, can not encode in a computer system. An example of this is seen in the process of copying texts if they know the procedure to copy files. The contradiction is how to select the texts. It can take from a fragment encoding to any encoding step.

The student has assimilated the contradiction contained in the problem situation and is oriented toward what to look for. Represents the sought. The problem must be well developed so that students can provide elements in the search for the unknown, but gives no solution pathways.
Different authors consulted (Claudio, 2003; Borrego, 2004; Exposito, 2010) among others, consider the approach as a proposed project that contributes to the development of the cognitive activity of students. Exposito (2010) argues that it is a general educational approach aims to encourage the teaching of core content computer, covered in a course, through a project approach to undertake in this course, is characterized by the subdivision of the project partial problems, necessary and motivating at the same time learning the new digital content.

It is the author's opinion that each phase of the project should encourage the production of new knowledge to the solution of the problem that caused partial contradiction. Students cooperate in solving the problem is solved in several joint sessions. This approach fosters collaborative learning among students.

Authors like Echaluce Alberto (2002), Claudio Marcelo Périssé (2003), Manuel Angel Bracho (2003), Adolfo García Pain (2003), among others, have been raised about the computer project definitions. However, it is the author's opinion that the definitions in the literature worked not represent the generality of the situations that may be encountered in solving computer projects so assumes the following definition: Plan of action as a matter of system, which integrates the actions by its developers, who contribute to the solution of a problem in a particular area of human knowledge which is involved in the use of at least one computerized system to provide appropriate solution and generate a product.

What are the defining characteristics raised?

1. It is a plan of action: It means that the student or students, in computer developers, must perform a series of actions to solve your project and that these actions have an inclusive in which the solutions are not isolated or outside the context of their work in solving the project.

2. Where are integrated actions by its developers: It implies that the solution of the project involved the cooperation of its members in solving tasks, in the case of the project in an educational context are the students, the teacher and users system, is of an eminently social in the acquisition of knowledge to the solution as the concatenation of the solutions provided by each depending on their roles in building the software product.

3. The problem represents a sphere of human knowledge: Computer penetration in the branches of human knowledge it has raised challenges in producing quality products and competitive computer.

4. With the use of at least one computer system: In this case addresses the issue of the use of one or more computer systems for solution since otherwise there is a computer project. The optimization of computing resources in solving tasks is very important for satisfying customer needs regarding equipment. In the case of this thesis is the use of a programming language for their solution.

5. Generate a product: The introduction of information technology in the production process involves generating assets in this project members have a role in its preparation to face the creation of products necessary for the efficient solution of the problem generated by the project. 
The project approach has traditionally referred to the teacher the title role in determining the projects to be undertaken by students, but the author believes that it is a situation that can be varied. Students may propose projects based on the needs of school computerization or business where the practice was followed. During the discovery process of the need for computerization school the student sets goals, objectives and projects with an autonomous and individualized; important elements to consider for the development of creativity

The approach promotes the development project in the student for the solution, the creative person indicators among which one can mention the questioning, reflection, custom framing, proper valuation and intellectual daring. The student acquires greater role in the process of teaching and learning can be assessed based on the level of completion of the project which is found in experiments.

The project approach proposed by the author proposes to solve the task in which they integrate knowledge based on the core concept is being called by the author as a project with minimum requirements. The solution of the project with minimum requirements for a student involves a set of basic knowledge that should be included in the project to be evaluated. Based on these minimum requirements are structured problematic situations that the author has termed as problémicos nodes associated with the project.

The concatenation of problematics nodes and relationships established between them to solve the project is one of the fundamental aspects of the system approach in the teaching of Information Technology (Gonzalez, 2010).

However, when analyzing the approaches previously raised the author considers that it is necessary to answer the following questions:

Do you keep these theoretical postulates of problematic situations when presented to students integrated into a project?

Will you continue the categories of teaching problem earlier conception, amended or deleted some to move from a problem situation to various educational problems?

In this environment the problem situation is different when the teacher presents the contradiction to all students when it becomes a personal problem by differentiating each of the projects. The author believes that from this time is encouraged greater commitment and motivation of the student because he chooses to solve the problem through your project. Thus contradictions are different for each student but general knowledge is the same, thus contributing to personal development.

The teaching problem is characterized by the formation of the contradiction between the known and the unknown structured by the teacher. In the problematic approach integrated with the project approach, the author believes that the contradiction can be structured in two ways substantially different:

1. enunciated by the teacher.

2. emanating from the solution of the project submitted by the student.

For the student has a higher level of demand since they face several problematic situations (along the theme) different in context to his and the outcome (knowledge) should be reformulated in terms of their problem be solved, an important element in structuring its scope.
Another edge of the situation is the approach by the student problems that may lead to the solution of your project, which encourages questioning, for problems that contributes to the development of creativity. Starting from the first solution the student is able to set goals in their development.

The resolution of the student project faces different types of problematic situations described above. In solving each form different working strategies that incorporate the significant information system owned by the individual and allows them to apply them to the solution of other situations.

The problematic situations are not made solely by the teacher since he can select one of the projects and, in this way, students are an active part of the teaching process needs to be considered as a way for the introduction of new knowledge. From student practice, linked to knowledge, problematic situations are taken. The teacher now not part of their experience but starts to work on the basis of the problems presented by students arising from the practice of these. They are students who set the tone for the structuring of new knowledge from each of its projects and the level of development of each.

The author of the thesis considers these interlocking problematics elements for the solution of the proposed project by students problematics nodes are associated with the project, and may take the form of teaching problems depending on the level of development achieved by the student in solving the project. However, in their approach during the joint solution can take the form of problem situation for other students to be presented by the teacher. Each of the nodes problematics uniquely reflected, although closely related to the core concepts, the expression and significance acquired for the subject.

The characteristics of problematic situations in the context of a project, the author believes that the following are from the teacher - student project in the solution:

1. Appear as system is not only determined by the teacher: The teacher selects the problem situation to work in whole class situations based on what problematic category. The student takes an active role in the teaching - learning. It is important for the teacher does not always take the same student. In this context, this feature is not fortuitous but is a regular for the essence of the process that differentiates it from other educational contexts.

2. They reflect the contradictions of an individual project, to meet the objectives of the year: Students are in class expressed the individuality of their projects, but the concepts and / or procedures obtained are common knowledge to all projects. The minimum teaching contents expressed in all projects are subordinate to the goals of the year to be defeated by the students.

3. The methodological structure of problematic situations by the teacher: The student meets the problem situation, however the fundamental impulse to search for its solution are given by the teacher. The teacher must continually prepare for structuring the main contradictions of projects and know the levels found in each of these. Thus the level of communication teacher - student must be high.

4. The integration of problematic situations arising from the project and its solution by the students: The inte- 
gration of problematic situations in a system where the solution of each forms a part of the project and in turn part of the next contradiction . In this continuum of problematic situations is structured class system and the project is resolved.

5. To promote higher levels of student research: Individualization of cognitive tasks involve more students in the process and increases the responsibility assumed by their learning in the form of a project. This work has the student perform an extensive search of the literature on the subject, starting with the help of the system used in the solution of your project and apply the conclusions to which up to the solution of different problems.

Structuring the sequence of problematic situations in line with the practice of students leads to precise control of each of the projects and possible ways to solve them. It is very important that you take a project for class work to introduce new knowledge but at the same time is affordable to all students and encourages development to the project initially worked.

Generally considered the author substantially changing the structure of the problematic situations for several reasons which are summarized below:

1. Using the student practice in structuring contradictions.

2. Students already know the possible contradictions and worked in them even when they do not know whether it will be taken by the teacher.

3. Greater individualization and independence of the contradictions and therefore more diversity should be addressed by the teacher.

4. Staff preparation by the teacher to attend to individual differences because they are the future contradictions to be used in classes.

Consider the author of this paper that the integration of project approach to teaching problem "traditional" leads to a higher level of problematic and individualized teaching that contributes to the development of creativity as it takes into account the individual characteristics are encourages problematic determination of reality that take the form of projects, among others.

It is the author's opinion that the integration of teaching problem and project-based learning encourages students in solving contradictions related to a project and involves students in the process of teaching - learning. Students have a greater role in the process while the level of demand rises. Are the projects developed by the students, in coordination with teachers from practice, and the contradictions found in its solution, which constitute the links of a harmonized system of teaching.

In the project solution affective elements involved as decision making in the design of the software and its interface, reflections on their efficiency among other issues in the development of creativity that transforms the person into a gradual and incremental process continuously and intentional.

\section{METHOD}

Two experiments were conduced to demonstrate the validity of the theoretical underpinnings discussed in the introduction in the Republic of Cuba and the Republic of
Angola. In the Cuban case is taken as follows groups of the third year of the course during the course Industrial Engineering 2004 - 2006 which is the population of this race. The first experiment will be addressed in later and try the second from where indicated.

Enforcement actions of the results proposed in the current conditions of teacher training aims of the experiment I: compare the results obtained by the students in the experimental group using the proposed methodology in the teaching of the content of programming with those obtained in the control group that is running the traditional way of teaching.

In the experience applied to the two groups, the following variables were monitored outside:

1. Ratio of number of students per computer, set at four, achieving this balance is maintained in separate activities.

2. Remedy the shortage of literature with the help of digital teaching materials on the intranet and, among them, obtained on the Internet.

3. Similar teaching hours for the subject in the control group that stayed with the traditional way of teaching and experimental group which introduced the proposal.

I experiment Hypothesis: If in the process of teaching learning programming is introduced by the teacher developed the project approach will help to develop creativity in students of higher education.

Were identified as independent variable approach proposed projects to help develop creativity in students of higher education as the dependent variable and the development of creativity of students in the learning process of this content.

\section{A. Experiment I}

Table \# 5: Results of assessments applied to students in the experiment. The results obtained using a programming language were lower as shown in the table $\mathrm{V}$ below.

TABLE V.

\begin{tabular}{|l|c|c|c|c|c|c|c|c|}
\hline Group & \multicolumn{2}{|l|}{ Flexibility } & \multicolumn{2}{l|}{ Autonomy } & \multicolumn{2}{l|}{ Generation } & \multicolumn{2}{l|}{ Extention } \\
\hline Control & 2 & $23.5 \%$ & 1 & $17.6 \%$ & 2 & $17.6 \%$ & 2 & $23.5 \%$ \\
\hline Experimental & 1 & $0 \%$ & 0 & $5.2 \%$ & 1 & $10.5 \%$ & 0 & $10.5 \%$ \\
\hline
\end{tabular}

Initial test is applied to both groups that is in them which presents a problem and the results are tabulated in (Table V). In the test given students do not develop efficient algorithms or models appropriate for the situation that they face. Few students can express various solutions to the issues raised. From the results of the survey and the initial diagnosis was decided to choose the I - 21 as control and I - 22 as experimental.

\section{B. Experiment II}

In the case of Angola takes a group during the years 2008 -2009 for being the people of this race to the Faculty of Engineering of the University Augustino Neto. For this experiment had no control group and were not performed on subjects but Database Programming, Software Engineering and Information Processing to do in different subjects. Groups were taken third year engineering courses 2010 and 2011. 
Given these characteristics of the experiment aims II: compare results obtained by students in the group at different periods in the teaching of computer science content. The experience applied to these groups, the following variables were controlled outside:

1. Ratio of number of students per computer in every case all students possess personal computer.

2. Remedy the shortage of literature with the help of digital teaching materials obtained on the Internet.

3. Similar time teachers for different subjects over the years.

Experiment Hypothesis II: If in the process of teaching - learning of computer is introduced by the teacher developed the project approach will help to develop creativity in students of higher education.

Were identified as independent variable approach proposed projects to help develop creativity in students of higher education as the dependent variable and the development of creativity of students in the learning process of this knowledge.

\section{1) Results: Experiment I}

Applied the second screening test aimed at assessing the implementation of the methodology. The results of the tabulation of the second screening test (Table 6) can express that:

1. The results in the test on the experimental group showing progress in comparison with the results of onset, it argues that the influence of the application of the methodology.

2. The results of the second test in amount assessed (Table 6) shows that the number of students expressed in percentage is not much higher in the experimental group, the results of the control group, but denotes better in the experimental group that in the control group.

A third assessment applied in students the results obtained in (Table VI) which can obtain the following results:

1. The results of the test conducted in the experimental group showing progress in comparison with the results of the above test, it argues that the influence of the application of the methodology.

2. The results of this evaluation (Table 6) shows that the number of students expressed in percent and is higher in the experimental group, the results of the control group.

In applying the last control students obtained the results expressed in (Table 6) that it is lawful to ask:

1. The results of the test conducted in the experimental group showed significant advances as compared with previous test results and initial testing, it argues that the influence of the application of the methodology.

2 . The second test results in number of evaluated (Table 6) shows that the number of students expressed in percent and is higher in the experimental group, the results of the control group

At the end of this experiment is applied a survey to students whose results (Table VII) allow students to express programming considered as important to your life, are interested in the subject and has application in their professional lives.
During the experiment was controlled the development of creativity computing students from the guide classroom observation by the teacher taking into account indicators and other important indicators set forth in this article. Professional interests in conjunction with cognitive interests are important indicators to diagnose emotional orientations with programming skills shown in Table VIII.

Based on the results of observation classes the author believes that students achieved in professional intentions related to programming, which allows to state that during the experiment to some changes in the psychological training of students. This conclusion is a factor to be taken into account by stating that the proposed methodology contributes to the development of creativity in students.

TABLE VI.

RESULTS OF EVALUATIONS

\begin{tabular}{|c|c|c|c|c|c|c|c|c|c|}
\hline Evaluations & Grouf & \multicolumn{2}{|c|}{ Flexibility } & \multicolumn{2}{|c|}{ Autonomy } & \multicolumn{2}{|c|}{ Generation } & \multicolumn{2}{|c|}{ Extention } \\
\hline \multirow{2}{*}{$\mathbf{l}$} & $\mathrm{C}$ & 5 & $29,41 \%$ & 5 & $29,41 \%$ & 4 & $23,52 \%$ & 6 & $35,29 \%$ \\
\cline { 2 - 10 } & $\mathrm{E}$ & 6 & $35,29 \%$ & 7 & $41,17 \%$ & 6 & $35,29 \%$ & 6 & $35,29 \%$ \\
\hline \multirow{2}{*}{$\mathbf{2}$} & $\mathrm{C}$ & 6 & $35,29 \%$ & 5 & $29,41 \%$ & 6 & $35,29 \%$ & 6 & $35,29 \%$ \\
\cline { 2 - 10 } & $\mathrm{E}$ & 12 & $70,59 \%$ & 13 & $76,47 \%$ & 11 & $64,70 \%$ & 14 & $82,35 \%$ \\
\hline \multirow{2}{*}{3} & $\mathrm{C}$ & 7 & $41,18 \%$ & 6 & $35,29 \%$ & 7 & $41,18 \%$ & 6 & $35,29 \%$ \\
\cline { 2 - 9 } & $\mathrm{E}$ & 16 & $94,12 \%$ & 16 & $94,12 \%$ & 15 & $88,23 \%$ & 16 & $94,11 \%$ \\
\hline
\end{tabular}

TABLE VII

RESULTS OF THE SURVEY.

\begin{tabular}{l|c|c|c|c|c|c|c|c|}
\cline { 2 - 9 } & \multicolumn{2}{c|}{1} & \multicolumn{2}{|c|}{2} & \multicolumn{2}{|c|}{4} & \multicolumn{2}{|c|}{5} \\
\cline { 2 - 9 } & C & E & C & E & C & E & C & E \\
\hline Affirmatively & 6 & 15 & 6 & 17 & 8 & 16 & 8 & 16 \\
\hline Negatively & 11 & 4 & 11 & 2 & 9 & 3 & 9 & 3 \\
\hline
\end{tabular}

TABLE VIII.

RESULTS OF OBSERVATION OF STUDENTS IN CLASSES.

\begin{tabular}{|c|c|c|c|c|c|c|c|c|}
\hline & \multirow{2}{*}{\multicolumn{2}{|c|}{ Group }} & \multicolumn{3}{|c|}{ Cantidad } & \multicolumn{3}{|c|}{ percertagems } \\
\hline & & & $1^{\text {era }}-2^{\text {d }}$ & $2^{d x}-3^{\text {ers }}$ & $3^{\text {ers }}-4^{\text {ta }}$ & $1^{\text {era }}-2^{\text {da }}$ & $2^{d x}-3^{\text {ers }}$ & $3^{\text {ers }}-4^{\text {ts }}$ \\
\hline \multirow{8}{*}{$\begin{array}{c}\text { Professionals } \\
\text { Skill }\end{array}$} & \multirow[t]{2}{*}{1} & $\mathrm{C}$ & 3 & 4 & 6 & 17,65 & 23,53 & 35,29 \\
\hline & & $E$ & 5 & 10 & 14 & 26,32 & 52,63 & 73,68 \\
\hline & \multirow[t]{2}{*}{2} & $\mathrm{C}$ & 4 & 5 & 5 & 23,53 & 29,41 & 29,41 \\
\hline & & $\mathrm{E}$ & 4 & 11 & 15 & 21,05 & 57,89 & 78,95 \\
\hline & \multirow[t]{2}{*}{3} & $\mathrm{C}$ & 4 & 5 & 6 & 23,53 & 29,41 & 35,29 \\
\hline & & $E$ & 5 & 12 & 16 & 26,32 & 63,16 & 84,21 \\
\hline & \multirow[t]{2}{*}{4} & $\mathrm{C}$ & 6 & 7 & 7 & 35,29 & 41,18 & 41,18 \\
\hline & & $\mathrm{E}$ & 5 & 12 & 15 & 26,32 & 63,16 & 78,95 \\
\hline \multirow{6}{*}{$\begin{array}{l}\text { Cognitive } \\
\text { Interest }\end{array}$} & \multirow[t]{2}{*}{1} & $\mathrm{C}$ & 4 & 5 & 6 & 23,53 & 29,41 & 35,29 \\
\hline & & $E$ & 5 & 10 & 18 & 26,32 & 52,63 & 94,74 \\
\hline & \multirow[t]{2}{*}{2} & $\mathrm{C}$ & 5 & 6 & 7 & 29,41 & 35,29 & 41,18 \\
\hline & & $\mathrm{E}$ & 6 & 11 & 16 & 31,58 & 57,89 & 84,21 \\
\hline & \multirow[t]{2}{*}{3} & $\mathrm{C}$ & 3 & 6 & 7 & 17,65 & 35,29 & 41,18 \\
\hline & & $\mathrm{E}$ & 5 & 12 & 16 & 26,32 & 63,16 & 84,21 \\
\hline \multirow[t]{8}{*}{ Motivation } & \multirow[t]{2}{*}{1} & $\mathrm{C}$ & 3 & 4 & 6 & 17,65 & 23,53 & 35,29 \\
\hline & & $\mathrm{E}$ & 4 & 12 & 15 & 19,05 & 57,14 & 71,43 \\
\hline & \multirow[t]{2}{*}{2} & $\mathrm{C}$ & 4 & 5 & 5 & 23,53 & 29,41 & 29,41 \\
\hline & & $E$ & 4 & 12 & 16 & 19,05 & 57,14 & 76,19 \\
\hline & \multirow[t]{2}{*}{3} & $\mathrm{C}$ & 4 & 5 & 6 & 23,53 & 29,41 & 35,29 \\
\hline & & $E$ & 6 & 14 & 18 & 28,57 & 66,67 & 85,71 \\
\hline & \multirow[t]{2}{*}{\begin{tabular}{|l|}
4 \\
\end{tabular}} & $\mathrm{C}$ & 6 & 7 & 7 & 35,29 & 41,18 & 41,18 \\
\hline & & $E$ & 4 & 11 & 16 & 19,05 & 52,38 & 76,19 \\
\hline \multirow{8}{*}{$\begin{array}{c}\text { Others } \\
\text { Indicators }\end{array}$} & \multirow[t]{2}{*}{1} & $\mathrm{C}$ & 4 & 5 & 6 & 23,53 & 29,41 & 35,29 \\
\hline & & $E$ & 5 & 11 & 17 & 26,32 & 57,89 & 89,47 \\
\hline & \multirow[t]{2}{*}{2} & $\mathrm{C}$ & 5 & 6 & 6 & 29,41 & 35,29 & 35,29 \\
\hline & & E & 6 & 12 & 17 & 31,58 & 63,16 & 89,47 \\
\hline & \multirow[t]{2}{*}{3} & $\mathrm{C}$ & 5 & 6 & 6 & 29,41 & 35,29 & 35,29 \\
\hline & & E & 4 & 11 & 15 & 21,05 & 57,89 & 78,95 \\
\hline & \multirow[t]{2}{*}{\begin{tabular}{|l|}
4 \\
\end{tabular}} & $\mathrm{C}$ & 4 & 5 & 5 & 23,53 & 29,41 & 29,41 \\
\hline & & $\mathrm{E}$ & 5 & 10 & 16 & 26,32 & 52.63 & 84,21 \\
\hline
\end{tabular}




\section{Experiment II}

We start the experiment from August 2009 to December 2010 with a group of third year of Computer Engineering and take the second set in January 2010 through December 2011. SE students decide to apply an amount of four cuts to standardize the number of tests performed as part of the outside variables involved. In this experiment different subjects were used as those used in Cuba. This ensures that the results are independent of a specific knowledge of computing.

It applies to students of both groups in a first cut which shows a low level of development of the dimensions that characterize creativity in computer science. The second cut is made in order to assess the application of the methodology. The results of the tabulation of the second screening test (Table IX and $\mathrm{X}$ ) which can express the results in the second cut made to groups of students show progress compared with the results of the home, which argues the influence of the implementation of the proposal.

By applying third student assessment results were obtained in (Table IX and $\mathrm{X}$ ) which allow to obtain the following results: The results in the cut made to the displayed group students progress compared to the previous test results, it argues that the influence of the implementation of the proposal.

From the third cut students obtained the results expressed in (Table IX and X) that it is lawful to ask: The results of subsequent cuts made to group students show significant progress compared to previous test results and the initial test, which argues the influence of the implementation of the proposal.

During the experiment controlled the development of creativity computing students from the guide classroom observation by the teacher taking into account indicators and other important indicators set forth in this article. Professional interests in conjunction with cognitive interests are important indicators to diagnose emotional orientations with programming skills shown in Table XI and XII.

Based on the results of observation classes the author believes that students achieved in professional intentions associated with the computer, what can be said that during the experiment to some changes in the psychological training of students. This conclusion is a factor to be taken into account by stating that the proposed methodology contributes to the development of creativity in students.

TABLE IX.

RESULTS FORM THE I IN THE ANGOLA REPUBLIC

\begin{tabular}{|c|c|c|c|c|c|c|c|c|c|c|}
\hline \multirow{2}{*}{$\begin{array}{l}\text { Year } \\
2008\end{array}$} & \multirow{2}{*}{$\begin{array}{c}\text { Cort } \\
1\end{array}$} & \multirow{2}{*}{\begin{tabular}{|c|} 
Group \\
I \\
\end{tabular}} & \multicolumn{2}{|c|}{ Flexibility } & \multicolumn{2}{|c|}{ Autonomy } & \multicolumn{2}{|c|}{ Generation } & \multicolumn{2}{|c|}{ Extention } \\
\hline & & & 1 & $14,29 \%$ & 2 & $28,57 \%$ & 1 & \begin{tabular}{|l|}
$14,29 \%$ \\
\end{tabular} & 2 & $28,57 \%$ \\
\hline & 2 & I & 2 & $28,57 \%$ & 2 & $28,57 \%$ & 1 & $14,29 \%$ & 2 & $28,57 \%$ \\
\hline & 3 & I & 3 & $42,86 \%$ & 3 & $42,86 \%$ & 2 & $28,57 \%$ & 4 & $57,14 \%$ \\
\hline & 4 & I & 4 & $57,14 \%$ & 3 & $42,86 \%$ & 3 & $42,86 \%$ & 5 & $71,43 \%$ \\
\hline Year & Corts & Group & \multicolumn{2}{|c|}{ Flexibility } & \multicolumn{2}{|c|}{ Autonomy } & \multicolumn{2}{|c|}{ Generation } & \multicolumn{2}{|c|}{ Extention } \\
\hline \multirow[t]{4}{*}{2009} & 1 & I & 5 & $71,43 \%$ & 5 & $71,43 \%$ & 4 & \begin{tabular}{|l|}
$57,14 \%$ \\
\end{tabular} & 6 & $85,71 \%$ \\
\hline & 2 & I & 5 & $71,43 \%$ & 5 & $71,43 \%$ & 4 & $57,14 \%$ & 6 & $85,71 \%$ \\
\hline & 3 & I & 5 & $71,43 \%$ & 6 & $85,71 \%$ & 5 & $71,43 \%$ & 6 & $85,71 \%$ \\
\hline & 4 & I & 6 & $85,71 \%$ & 7 & $100,00 \%$ & 6 & $85,71 \%$ & 6 & $85,71 \%$ \\
\hline
\end{tabular}

TABLE X.

RESULTS OF GROUP I IN THE ANGOLA REPUBLIC DURING 2010 AND 2011

\begin{tabular}{|c|c|c|c|c|c|c|c|c|c|c|}
\hline \multirow{2}{*}{$\begin{array}{l}\text { Year } \\
2010\end{array}$} & \multirow{2}{*}{$\begin{array}{c}\text { Corts } \\
1\end{array}$} & \multirow{2}{*}{\begin{tabular}{|c|} 
Group \\
II \\
\end{tabular}} & \multicolumn{2}{|c|}{ Flexibility } & \multicolumn{2}{|c|}{ Autonomy } & \multicolumn{2}{|c|}{ Generation } & \multicolumn{2}{|c|}{ Extention } \\
\hline & & & 2 & $16,67 \%$ & 1 & $8,33 \%$ & 2 & $16,67 \%$ & 3 & $25,00 \%$ \\
\hline & 2 & II & 2 & $16,67 \%$ & 2 & $16,67 \%$ & 3 & $25,00 \%$ & 3 & $25,00 \%$ \\
\hline & 3 & II & 3 & $25,00 \%$ & 4 & $33,33 \%$ & 5 & $41,67 \%$ & 4 & $33,33 \%$ \\
\hline & 4 & II & 5 & $41,67 \%$ & 5 & $41,67 \%$ & 7 & $58,33 \%$ & 5 & $41,67 \%$ \\
\hline \multirow{5}{*}{$\begin{array}{l}\text { Year } \\
2011\end{array}$} & Corts & Group & \multicolumn{2}{|c|}{ Flexibility } & \multicolumn{2}{|c|}{ Autonomy } & \multicolumn{2}{|c|}{ Generation } & \multicolumn{2}{|c|}{ Extention } \\
\hline & 1 & II & 6 & $50,00 \%$ & 8 & $66,67 \%$ & 7 & $58,33 \%$ & 7 & $58,33 \%$ \\
\hline & 2 & II & 8 & $66,67 \%$ & 9 & $75,00 \%$ & 8 & $66,67 \%$ & 7 & $58,33 \%$ \\
\hline & 3 & II & 10 & $83,33 \%$ & 9 & $75,00 \%$ & 10 & $83,33 \%$ & 8 & $66,67 \%$ \\
\hline & 4 & II & 11 & $91,67 \%$ & 10 & $83,33 \%$ & 11 & $91,67 \%$ & 9 & $75,00 \%$ \\
\hline
\end{tabular}

TABLE XI.

RESULTS OF OBSERVATION OF STUDENTS IN CLASSES FOR THE GROUP

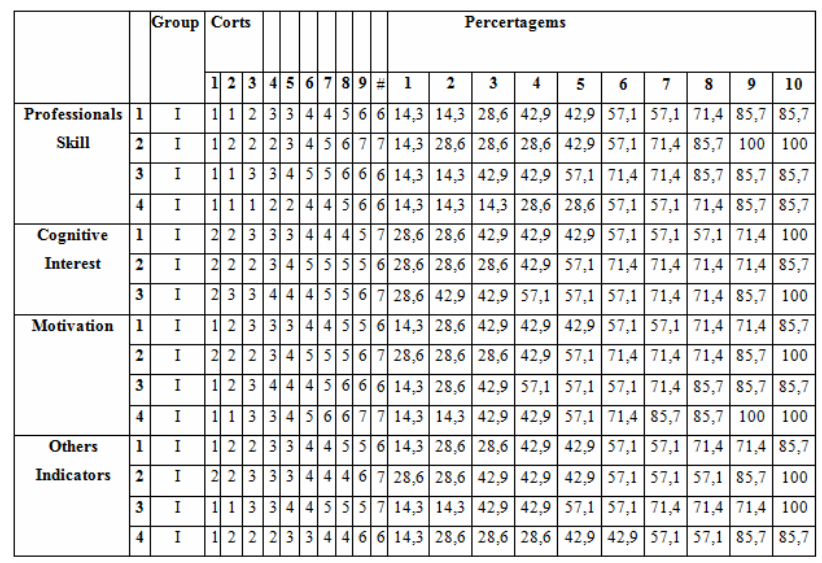

TABLE XII.

RESULTS OF OBSERVATION OF STUDENTS IN CLASSES FOR THEGROUP II

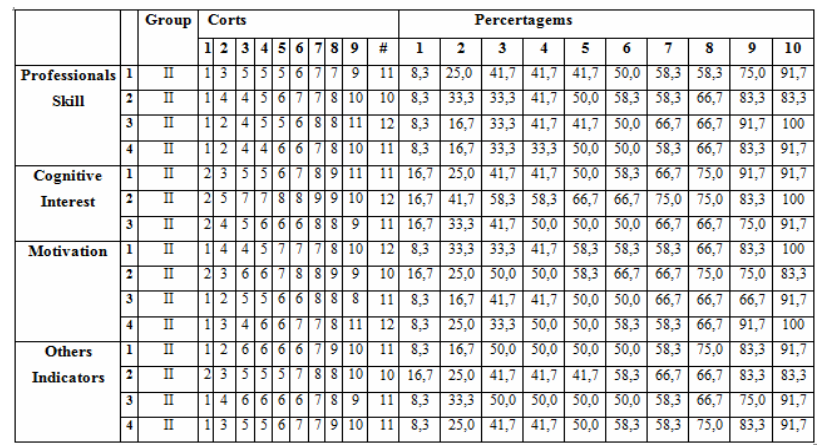

TABLE XIII.

RESULTS OF PSPP OPEN SOURCE SOFTWARE.

\begin{tabular}{|c|c|c|c|c|c|c|}
\hline & & $\begin{array}{l}\text { Suma de } \\
\text { Cuadrados }\end{array}$ & df & $\begin{array}{l}\text { Cuadrado } \\
\text { medio }\end{array}$ & & Significatividad \\
\hline \multirow[t]{3}{*}{ Flexibility } & Entre Grupos & 64,05 & 2 & 32,02 & 2,28 & 13 \\
\hline & Intra Grupos & 238,50 & 17 & 14,03 & & \\
\hline & Total & 302,55 & 19 & & & \\
\hline \multirow[t]{3}{*}{ Autonomy } & Entre Grupos & 63,67 & 2 & 31,84 & 2,09 & .15 \\
\hline & Intra Grupos & 258,88 & 17 & 15,23 & & \\
\hline & Total & 322,55 & 19 & & & \\
\hline \multirow[t]{3}{*}{ Generation } & Entre Grupos & 80,68 & 2 & 40,34 & 3,36 & 06 \\
\hline & Intra Grupos & 204,13 & 17 & 12,01 & & \\
\hline & Total & 284,80 & 19 & & & \\
\hline \multirow[t]{3}{*}{ Extention } & Entre Grupos & 49,00 & 2 & 24,50 & 1,83 & 19 \\
\hline & Intra Grupos & 227,00 & 17 & 13,35 & & \\
\hline & Total & 276,00 & 19 & & & \\
\hline
\end{tabular}


Three experimet discussed above is taken as independent sample data and calculate the variance for independent samples with the following results in table XIII using pspp open source software. The result obtained in the last column suggets that not exist a large variations in the three examples and therefore, in general, it is concluded tha the project focus approach contributes to development creativity on informatics educations.

\section{Which concluded that:}

The proposal contributes to the development of creativity in computing students from raising the number of students with the dimensions proposed in this thesis and considering indicators expressed above (flexibility, generation, extension and autonomy).

In general, it can be concluded that the results obtained by the experimental group at the end of the courses are superior to those of the control group compared with those obtained at the beginning of the course and during the experiment in the case of the experiment in Cuba, arguments allow compliance support the hypothesis for this stage and say that the target of the experiment in the validation stage. Although we demonstrate the development of creativity in the experimental group did not reach the same development at all is possible to distinguish three main groups of creative students on the basis of observation and experiments conducted classes:

Level I: These students have a high level of cognitive interests which makes owning a deep information about the computer and use in solving problems. They are highly independent in finding and solving the problems that occur in developing programming making several models, algorithms and codes that result in the production of more efficient systems from theoretical considerations. Recepcionar are capable of improving the critical and optimally mentioned system elements which results in an increase in quality. The integration of the programming career itself is done, quickly incorporates programming knowledge to their specialty. Define the various problems and their solutions taking into account the conditions in which they operate. They are very persistent in solving problems and in their integration with the knowledge of their specialty.

Level II: These students have a good level of cognitive interests that do have information about the programming language and use it in problem solving. They are independent in finding and solving the problems that occur in making programming modeling, algorithms and codes that result in the production of more efficient systems from theoretical considerations. Recepcionan critique and improve system elements identified that result in increased quality. The integration of the computer to his career is done in a proper way but sometimes have to rely on help, incorporates programming knowledge to their specialty. Define the various problems and their solutions taking into account the conditions in which they operate. They are persistent in solving problems and in their integration with the knowledge of their specialty.

Level III: These students developed a low level of creativity in computer science as indicators integrated behavior discussed above. They have no depth information on the programming language and although the information they have at certain times can be used in solving problems. They are dependent on finding and resolving problems some practice so are unable to develop own prob- lems and computer elements of programming for the solution of problems. They can recepcionar criticism although the low level of knowledge reached not optimally improves system elements identified. The integration of the computer to his career is not done in a proper way. Achieved with difficulty defining problems and solutions for it taking different models, algorithms or classes encodings. There are persistent in solving problems. The number of students achieving different levels in the experiment can be broken down into 9 students on the first level, 7 in the second level and 3 students in the third level.

\section{CONCLUSIONS}

The development of the pilot phase allowed reaching the following conclusions:

1. Two experiments were conducted in completely different conditions, students of different levels and different knowledge systems, only variables remaining as similar behavioral approach to the introduction of the project and level of education.

2. The results obtained in the experiments allowed to assert the validity of the introduction of the project approach in teaching computer science to develop creativity.

\section{REFERENCES}

[1] Betancourt, J. (1997). La creatividad: bloqueos y temores. En La creatividad y sus implicaciones. La Habana: Academia.

[2] Bracho, M. A. (2003). Proyecto de un programa de gestión empresarial.

http://www.uhu.es/17117/Proyecto\%20de\%20un\%20programa\%2 0de\%20gestion\%20empresarial.ppt. Consultado en: 26/10/2004.

[3] Brito, H., Viviana, M. (1999). Psicología para los ISP. Tomo I. La Habana: Pueblo y Educación.

[4] Craft, A. (2008). Studying collaborative creativity: Implications for education. Thinking Skills and Creativity, 33, 241-245. http://dx.doi.org/10.1016/j.tsc.2008.09.006

[5] Crespo, T. (2000). La heurística en la enseñanza de la programación. Ponencia presentada al IV Evento Internacional La Enseñanza de la Matemática y la Computación. ISP “Juan Marinello”. Matanzas.

[6] D’Angelo, O. (2002). El Desarrollo Profesional Creador (DPC) como dimensión del Proyecto de Vida en el ámbito profesional. En: $\quad$ http://www.clacso.edu.ar/ libros/cuba/angelo2.rtf. Consultado 15/04/2006

[7] De Bono, E. (1992). Serious Creativity. Publisher: Harper Business.

[8] de la Torre, S. (2002). Creatividad en la reforma española. En http://educacion.jalisco.gob.mx/consulta/educar/10/10saturn.html. Consultada 12/02/2007

[9] De Prado, D. (2003). Creatividad para transformar sustancialmente las curriculares: una estrategia. En http://www.iacat.com/webcientifica/educrea\%20capitulo\%20V.pd f. Consultado 12/06/2007

[10] Deheane, S., Changeux, J., Naccache L., Sackur J., Sergent C. (2006) Conscious, preconscious, and subliminal processing: a testable taxonomy. Trends in cognitive sciences, 105, $204-210$. http://dx.doi.org/10.1016/j.tics.2006.03.007

[11] Echaluce, A. (2002). La elaboración de un proyecto informático. http://web.jet.es/inforpesca/pagina_n.htm. Consultado en: 20/12/2004

[12] Expósito, C. (2006). Elementos de Metodología de la Enseñanza de la Informática. Ciudad de la Habana: Pueblo y Educación..

[13] Glazer, E. (2009). Rephrasing the madness and creativity debate: What is the nature of the creativity construct? Personality and Individual Differences. 468, 755-764. http://dx.doi.org/10.1016/ j.paid.2009.01.021 


\section{Creativity DeVelopment in Informatics Teaching Using the Project Focus}

[14] González, W. (2005). Implicaciones de la inteligencia lógica matemática en el desarrollo de la creatividad informática. Recrearte.

http://www.iacat.com/Revista/recrearte/recrearte02/walfredo01.ht m.

[15] González, W. (2005). La formación de conceptos y definiciones informáticas. Revista Atenas, 12, 13-45

[16] González, W., Estrada, V. y Martínez, M. (2005). Propuesta metodológica para la formación del profesional informático desde la producción. Revista Atenas, 12, 64 - 72.

[17] González, F. (1985). Psicología de la personalidad. Fernando González Rey. Ciudad de la Habana: Pueblo y Educación.

[18] González, F. (1994). Psicología Humanista. Actualidad y desarrollo. Fernando

[19] González, F. (1995). Comunicación, personalidad y desarrollo. La Habana: Pueblo y Educación.

[20] González Valdés, A (1994). Prycrea. Desarrollo multilateral del pensamiento creador. La Habana: Ciencias Sociales.

[21] González, A. (1995). "Prycrea: pensamiento reflexivo y creatividad”. La Habana: Academia.

[22] González, A. (1990). Cómo propiciar la creatividad. La Habana: Ciencias Sociales.

[23] González, A. (1999). Conceptualización de la creatividad en PRYCREA. http://www.clacso.edu.ar/ libros/cuba/gonza2.rtf. Consultado 12/09/2007

[24] González, C. A. (2002). Creatividad en el escenario educativo Colombiano. Pedagogía y Currículum. OnLine: http://educacion.jalisco.gob.mx/consulta/educar/10/10carlos.html. Consultado 12/09/2007

[25] Kampylis, P., Berki E., Saariluoma P. (2009) In-service and prospective teachers' conceptions of creativity. Thinking Skills and Creativity, 41, 15-29 http://dx.doi.org/10.1016/j.tsc.2008. $\underline{10.001}$

[26] Kudriatsev,T.V.(1967) Algunos aspectos psicológicos y didácticos de la enseñanza problémica. Pedagogía Soviética, 810, 34-56.
[27] Labarrere, A. F. (1987) Bases psicopedagógicas de la enseñanza de la solución de problemas matemáticos en la escuela primaria. La Habana: Pueblo y Educación.

[28] Lee, J. (2003) Cognitive Complexity and Methodical Training: Enhancing or Suppressing Creativity. Jungwoo Lee, Duane P. Truex..

http://www.computer.org/proceedings/hicss/0493/04937/0493700 7.pdf. Consultado en: 22/9/2005

[29] Majmutov, M. I. (1983) La enseñanza problémica. La Habana: Pueblo y Educación.

[30] Martínez, M. (1980). La enseñanza problémica de la filosofía marxista leninista. La Habana: Ciencias Sociales.

[31] Martínez, M. (1999). El desarrollo de la creatividad mediante la enseñanza problémica en la actualidad. Teoría y práctica. Curso 6 Pedagogía 1999. La Habana.

[32] Martínez, M. (1995). Calidad educacional, actividad pedagógica y creatividad. La Habana: Academia.

[33] Pantoja, A. (2003). Influencia del LOGO en la capacidad creativa del niño del Tercer Ciclo de Educación Primaria. Tesis en Opción al grado científico de Doctor en Pedagogía. Universidad de Jaén.

[34] Romo, M. (1997). Psicología de la creatividad. Barcelona: Paidós.

[35] Zorana, I. (2009). Creativity Map: Toward the Next Generation of Theories of Creativity. Psychology of Aesthetics, Creativity and the Arts. 31, Pages 17-21

\section{AUTHORS}

Walfredo González. Graduate degree in education specialty of mathematics and informatics. Master on Didactic mention Mathematics educations and $\mathrm{PhD}$ of Pedagogical Sciences. Coordinates the Laboratories of Technologies in Educations of University of Matanzas. Has published over 15 papers in refereed journals.

Received 5 November 2012. Published as resubmitted by the author 18 December 2012 